$\begin{array}{ll}\text { Variants } & \begin{array}{l}\text { Variants } \\ \text { The Journal of the European Society for Textual } \\ \text { Scholarship }\end{array}\end{array}$

$12-13$ | 2016

Varia

\title{
Daniel Apollon, Claire Bélisle and Philippe Régnier (eds.), Digital Critical Editions
}

\section{Ronan Crowley}

\section{(2) OpenEdition \\ Journals}

Electronic version

URL: http://journals.openedition.org/variants/406

DOI: 10.4000/variants.406

ISSN: 1879-6095

\section{Publisher}

European Society for Textual Scholarship

\section{Printed version}

Date of publication: 31 December 2016

Number of pages: $276-280$

ISSN: 1573-3084

\section{Electronic reference}

Ronan Crowley, «Daniel Apollon, Claire Bélisle and Philippe Régnier (eds.), Digital Critical Editions », Variants [Online], 12-13 | 2016, Online since 01 May 2017, connection on 25 September 2020. URL : http://journals.openedition.org/variants/406 ; DOI : https://doi.org/10.4000/variants.406

This text was automatically generated on 25 September 2020 .

The authors 


\title{
Daniel Apollon, Claire Bélisle and Philippe Régnier (eds.), Digital Critical Editions
}

\author{
Ronan Crowley
}

\section{REFERENCES}

Daniel Apollon, Claire Bélisle and Philippe Régnier, eds. Digital Critical Editions. Urbana: University of Illinois Press, 2014. 368 pp. ISBN 978-0252-03840-2.

1 Born of the French-Norwegian collaborative network "Digital Publishing and Reading", Digital Critical Editions offers nine original and thought-provoking essays (and a valuable bibliography of online resources) to address the ongoing transition from print-based critical editing to its digital counterpart. Eschewing any epochal model that insists on decisive breaks, the emphasis instead is on the uneven, gradual nature of this development: on what the editors describe, in an elegant formulation, as " $[t]$ he slow intrusion of digital architectures into traditional editorial territories" (3). In her contribution, Sarah Mombert identifies this broad trend as constituting "a genuine editorial regime change" (247) in which the outward signs of media revolution belie more profound implications for the practice and protocols of editing. Accordingly, alongside the expected migration from paper-based to digital editing, the contributors also tackle such issues as the shift from paper-based presentation to the creation of digital research environments; the enrichment of scholarly practice made possible by new digital tools and technologies; the "Digital Fate" of the critical apparatus (the focus of chapter three); and new reading practices and editorial constructs concomitant with the digital turn.

2 The editors' introduction, “As Texts Become Digital", emphasizes a practical and practice-centred approach. More theoretical or epistemology-driven considerations are examined, but these are largely bracketed in favour of a fourfold matrix in which 
digital critical editing is located. The introduction canvases, in turn, the explosive growth in the production and accessibility of documents; the emergence of new tools and digital networks; the broader historical, cultural, and institutional framework in which editing is inscribed; and the coming to prominence of the reader or user in the consumption of the digital critical edition. Fully half of the chapters that follow are multi-authored. Coupled with repeat contributors, this collaborative spirit makes for a focused collection that circles and re-circles around a dominant set of preoccupations, arranged in three thematic clusters.

3 The first of these, "History, Challenges, and Emerging Contexts", opens with a chapter by Odd Einar Haugen and Daniel Apollon on the digital turn in textual scholarship. Beginning with a broad overview of the field's development since the nineteenth century, the authors identify three directions of inquiry - "editors may choose to look backward, outward, or inward" (35) - that correspond, respectively, with a transmission-centred focus on the development of text over time, with the situating of a text in its socio-historical context, and with unpacking the layers of meaning immanent in the literary work. All three directions have been subject to a dramatic shake-up in the wake of digital enhancement, assuredly, but the authors argue that the digital turn has not yet lead to a major upheaval in how we conceive of text per se.

In chapter two, Philippe Régnier strikes a similarly clearheaded note in his treatment of the major challenges and opportunities created for critical editing by digital technology. Instancing instructive examples from antiquity through the present day, he descries a "moral obligation" (58) for philology to remain true to its fundamental values as it responds to the manifold options that proliferating technologies make possible. His tone is cautionary, but he articulates an intriguing projection of a maximalist, pluralist "non-dogmatic philology" in step with the "boundless textuality" (77) of our time.

5 Apollon and Claire Bélisle temper this invocation of possibility in chapter three by addressing the afterlife of the print edition's conventions in the digital age. They contend that new tools for analysis and presentation return us to a state in which fluctuation and variance - "a generalized textual variability" (82) - are once again the norm. As the critical edition goes digital, the editor's challenge is to accommodate new readerships, to address changing expectations for the editorial apparatus, and to respond to the new frontier represented by the digital environment. The authors plump, reasonably enough, for Cerquiglinian variance. Gone is the singular, definitive edition; in its place, versions, paralipomena, and user-selected visualizations proliferate and constitute new ways of interacting with an expanded editorial object.

6 Chapter four on digital remediation and new reading practices rounds out the first part of the volume. Terje Hillesund and Bélisle look to the example of an earlier media shift, the transition from manuscript to the printed codex, to contextualize the transformations effected by the digital. A run-through of the long editorial engagement with Chaucer, which culminates in an analysis of the Canterbury Tales Project, paves the way for the authors' investigation of how remediation engenders new reading practices. Against widely circulating predictions of the demise of reading, they remind us that "the paper paradigm" (140) has its own history, and they advocate instead a model of reading irreducible to a solitary, silent practice.

7 Part two, "Text Technologies", comprises chapters five and six. In the first of these, Claus Huitfeldt provides a useful overview of markup languages, aimed primarily at 
textual scholars new to the intricacies of encoding. Recovering a history that runs from Standard Generalized Markup Language (SGML) through Hypertext Markup Language (HTML) and on to EXtensible Markup Language (XML), he sets out the case for some of generalized markup's most earnest shibboleths: standardization, sustainability, and the promise of longevity prominent among them. The introductory nature of the chapter hinders in no way valuable reflections on the theoretical underpinnings of markup and on the institutional considerations that are ensuring a future for XML even as the latest standardization struggles play themselves out.

With markup as something of a given, the focus of chapter six is on the affordances of the digital for critical editing. Taking wing from the principle of "separating transcription from presentation issues" (179), Alois Pichler and Tone Merete Bruvik draw on their respective experiences of working in the Wittgenstein Archives and for the Henrik Ibsen's Writings project. The chapter traces the implications of disambiguating transcription from presentation, a nuance underdeveloped in the paper-based scholarly edition, but which comes to the fore in the digital environment, enabling what the authors term "interactive dynamic editing" (181). The potential of the latter is for an altogether more democratic, more transparent process of edition making, one that positions the user as a picker and chooser from among the varieties of presentation options enabled by source transcriptions and metadata.

Opening part three on "New Practices, New Contexts, New Policies", Haugen surveys the historical development of textual editing from Alexandrian philology to the moment of the computer's intervention. His focus is exclusively on the editing of predigital texts, but it culminates in the application of computational phylogenetic analysis borrowed from the life sciences. The chapter addresses the interplay between qualitative and quantitative methods in modern editorial practice to articulate a typology of editing that extends along three dimensions: how a text should be reproduced; the degree to which an edition should reflect the growth of the text; and the question of which versions or states of a text should be prioritized.

In her contribution, Mombert explores the critical editing of "heterogeneous documents" (246). To broaden the object of inquiry to include audio and visual material, for example, or to look beyond the canon to the also-rans of the nineteenth century is also to invite a correspondingly broadened set of methodologies. The author delineates a changeover from the book regime, with its attendant editorial framework, to what she terms "the digital collection regime" (247). The digital collection, as yet undertheorized and typically equated with the "corpus" or "archive", represents a genuine novelty in the editorial landscape. Accordingly, Mombert offers valuable insights into how best the editor might establish the boundaries of a collection, impose organizational principles on its contents, or link its constituent documents.

The final chapter uses the frame of political economy to address commercial, political, and intellectual-property aspects of textual scholarship, first as a nineteenth century phenomenon, and subsequently in relation to the big text data being captured by Large-scale Digitization Initiatives like Google Books. Régnier describes in fascinating detail the "Livre à la carte" scheme of the late 1990s, which attempted to broaden access to public domain works held by major French libraries through digitization and limited print on demand. This leads him to make an impassioned case for the role of the editor in the current culture of mass scanning and remediation, and he argues 
forcibly that at stake is nothing less than thwarting a ring fence of the cultural commons.

The spectre of obsolescence or supersession (for the current state of digital editing as for its print forebear) hangs over much of the volume. On the other hand, some of the emancipatory rhetoric might grate: that underexamined term "dynamic", for example, recurs with suspicious frequency as though a denotation for server-side scripting has been lent the vigorousness of its more everyday acceptation (as one might speak of a "dynamic speaker", for example). It is a testament to the essayists' long perspective on textual scholarship and its shifting locus of inquiry, however, that the contributions are united not by anxiety or technological determinism but by thoughtful appraisal and a sober mixture of caution and optimism.

\section{AUTHORS}

\section{RONAN CROWLEY}

Ronan Crowley is Alexander von Humboldt Postdoctoral Research Fellow at Universität Passau. He took the PhD in English from the University at Buffalo in 2014 for a dissertation on transatlantic copyright regimes and Irish modernism. His research interests are in genetic criticism and the Irish Literary Revival. 